PRETHODNO PRIOPĆENJE

UDK: $336.76: 336.761$

Mario Kovačević *

Doc. dr. sc. Davor Zoričić **

Zrinka Lovretin Golubić ${ }^{* * *}$

\title{
PRIMJENA INDEKSA TEMELJENIH NA FUNDAMENTALNIM POKAZATELJIMA NA HRVATSKOME TRŽIŠTU KAPITALA
}

\author{
APPLICATION OF INDICES BASED ON FUNDAMENTAL \\ INDICATORS ON THE CROATIAN CAPITAL MARKET
}

SAŽETAK: U nastojanjima da se najpoznatiji jedno-faktorski model, model procjenjivanja kapitalne imovine (CAPM), primijeni u praksi često su se koristili dionički indeksi temeljeni na tržišnoj kapitalizaciji. Istraživanja su, međutim, pokazala da takvi indeksi najčešće ne predstavljaju efikasan portfolio svojih sastavnica pa su u posljednjih 10-ak godina razvijani pristupi koji bi investitorima trebali ponuditi efikasnije indekse. Istraživanja za hrvatsko tržište upućuju na otežanu primjenu takvih istraživanja zbog specifičnosti malog i nelikvidnog tržišta. U ovome radu kao alternativa tržišnoj kapitalizaciji testiraju se fundamentalni pokazatelji slijedeći istraživanje Arnott et al. (2005.). Ispituje se više fundamentalnih pokazatelja, a performanse indeksa uspoređuju se s CROBEX indeksom za revizije indeksa u razdoblju 2009. - 2016. Rezultati istraživanja pokazuju bolje performanse određenih testiranih indeksa u vidu većih odnosa rizika i nagrade, ali uz slabu robusnost. Također, veći odnosi rizika i nagrade proizlaze iz relativno većeg povećanja prinosa u odnosu na rizik što sugerira potrebu za provođenje daljnjih istraživanja.

KLJUČNE RIJEČI: CAPM, faktorski modeli, efikasni indeksi, indeksi temeljeni na fundamentalnim pokazateljima.

SUMMARY: In order to apply one of the most famous single-factor models (CAPM) in practice, equity market cap-weighted indices were often used. However, research has shown that such indices often do not represent efficient portfolios of their constituents. Therefore, various approaches have been developed in the last 10 years in pursuit of more efficient indices for investors. Research conducted for the Croatian market points out diffi-

Mario Kovačević, E-mail: mario.kovacevic01@gmail.com

** Doc. dr. sc. Davor Zoričić, Ekonomski fakultet Sveučilišta u Zagrebu, Trg J.F. Kennedyja 6, Zagreb, E-mail: dzoricic@efzg.hr

*** Zrinka Lovretin Golubić, Ekonomski fakultet Sveučilišta u Zagrebu, Trg J.F. Kennedyja 6, Zagreb, E-mail: zlovretin@efzg.hr 
culties in application of developed approaches due to specifics related to small and illiquid market. This research follows the work of Arnott et al. (2005) to test fundamental indicators as an alternative to cap-weighted indices. Several indicators have been tested and their performance is compared to CROBEX for revisions in the period 2009-2016. Research findings show better performance of certain indices through higher risk reward ratio but with low robustness. Higher risk reward ratios are due to relatively larger increase of the return in comparison with risk suggesting the need for further research.

KEY WORDS: CAPM, factor models, efficient indices, fundamentally-weighted indices.

\section{UVOD}

Sredinom prošloga stoljeća temeljem rada Markowitza (1952.) razvijena je Moderna portfolio teorija koja i danas predstavlja okvir za upravljanje portfoliom vrijednosnih papira i drugih oblika imovine. Optimizacija temeljem prinosa i rizika (engl. Mean-Variance optimization) u spomenutome radu omogućila je izvođenje skupa efikasnih portfolia (efikasna granica), a kasnija istraživanja tražila su i odgovor na pitanje koji je portfolio s efikasne granice za određenoga investitora najbolje izabrati. Ključni doprinos u tome smislu predstavlja rad Sharpea (1964.) u kojemu se optimalni portfolio s efikasne granice utvrđuje putem pravca tržišta kapitala (koji predstavlja tangentu na efikasnu granicu) i uvodi pojam sistematskog rizika. Time su postavljeni temelji najpoznatijega jedno-faktorskog modela u financijama, modela procjenjivanja kapitalne imovine (engl. Capital Asset Pricing Model), a ključ njegove primjene u praksi upravo leži u (ne)mogućnosti procjene optimalnog portfolia tržišne imovine budući da je u stvarnome svijetu neopaziv.

Ipak, koncepti predstavljeni CAPM-om toliko su bitni u znanosti i u praksi da su se počeli primjenjivati čak i uz značajno narušavanje pretpostavki samoga modela, iako u tome slučaju, kao što ističu Goltz i Le Sourd (2010.), ne vrijedi nužno da je optimalni tržišni portfolio (predstavljen u CAPM-u) efikasan. Jedna od ključnih razlika između pokušaja primjene modela u praksi i samoga CAPM-a često jest u tome što se primjena ograničava samo na dionička tržišta dok optimalni tržišni portfolio iz CAPM-a uključuje svu imovinu u nekoj ekonomiji. U takvim uvjetima (a pogotovo uz narušavanje i drugih pretpostavki modela) ne vrijede nužno zaključci vezani uz vrednovanje imovine prema beta koeficijentu jer sama beta ne predstavlja nužno mjeru sistematskog rizika. Drugim riječima, kao što navodi, primjerice Orsag (2015.) CAPM je poseban slučaj jedno-faktorskog modela u kojemu je temeljem definiranih pretpostavki moguće izvoditi zaključke. Ako se pretpostavke napuste, ti zaključci nužno ne vrijede, a model se svodi na drugačiji jedno-faktorski model čije mogućnosti korištenja treba sasvim zasebno istražiti.

Budući da u CAPM-u optimalni tržišni portfolio zapravo predstavlja indeks baziran na tržišnoj kapitalizaciji (kako bi se modelom moglo objasniti vrednovanje kapitalne imovine), u jedno-faktorskim modelima u praksi ${ }^{1}$ također se često koriste burzovni dionički

Ovdje bi se moglo navesti da takvi modeli slijede rad Markowitza (1959.), ali treba voditi računa da beta koeficijent u tome radu ima bitno drugačije implikacije od beta koeficijenta kojega opisuje Sharpe (1964.) godine što je posebno istaknuo Markowitz (1984.). 
indeksi bazirani na tržišnoj kapitalizaciji. Međutim, istraživanja krajem prošloga stoljeća poput Haugena i Bakera (1991.) i Grinolda (1992.) skrenula su pozornost na činjenicu da korištenje takvih indeksa ne nudi efikasan odnos rizika i nagrade investitorima, odnosno, da se takvi indeksi ne nalaze na efikasnoj granici svojih sastavnica. Kako ističu Amenc et al. (2006.) do toga dolazi zbog dva razloga. Prvi razlog se odnosi na izrazito veliku koncentraciju takvih indeksa jer najveće pondere imaju dionice s najvećom tržišnom kapitalizacijom, ${ }^{2}$ a drugi razlog leži u činjenici da ponderiranje nije temeljeno na kriteriju optimizacije vezanom uz izvođenje efikasne granice (optimizacije prema prinosu i riziku). Dakle, diversifikacija koju takvi indeksi nude je slaba i nije temeljena na ispravnom principu što rezultira neefikasnim portfolijem.

Temeljem navedenih kritika razvijeni su brojni pravci istraživanja kako bi se investitorima ponudili efikasniji indeksi, odnosno, indeksi s boljim odnosnom rizika i nagrade. Jedan od pravaca istraživanja nastoji procijeniti portfolio s najvećim Sharpeovim omjerom sastavnica nekog indeksa čime se rehabilitira CAPM (odnosno optimalni tržišni portfolio). U jednostavnijem slučaju umjesto optimalnog portfolia iz CAPM-a procjenjuje se portfolio s najmanjom varijancom koji predstavlja početak efikasne granice. Ostali pristupi uključuju maksimalnu dekorelaciju, paritet rizika, indekse temeljene na fundamentalnim pokazateljima i još neke pristupe o čemu je moguće više vidjeti u Amenc et al. (2013.).

Budući da nalazi istraživanja Zoričić et al. (2014.) za hrvatsko tržište sugeriraju da CROBEX indeks nije efikasan, a istraživanje Dolinar et al. (2017.) da je teško procijeniti portfolio s najvećim Sharpeovim omjerom izvan uzorka, u ovome radu istražuje se mogućnost primjene indeksa temeljenih na fundamentalnim pokazateljima na hrvatskome tržištu kako bi se investitorima ponudili efikasniji indeksi. Pritom treba istaknuti, kao što je moguće vidjeti u Amenc et al. (2008.) i Amenc et al. (2013.), da taj pristup nema uporište u financijskoj teoriji, odnosno, nije jasna njihova veza s modernom portfolio teorijom i CAPM-om. Upravo zbog navedenoga, bitan dio ovoga rada čini komentar dobivenih rezultata u kojemu se ističe potreba provođenja daljnjih istraživanja kako bi se ispitale značajke faktorskih modela temeljenih na fundamentalnim pokazateljima za hrvatsko tržište kapitala.

\section{INDEKSI TEMELJENI NA FUNDAMENTALNIM POKAZATELJIMA}

Temeljem spomenutih kritika dioničkih indeksa temeljenih na tržišnoj kapitalizaciji u uvodnome dijelu rada, početkom ovoga stoljeća pojavili su se, između ostaloga, dionički indeksi temeljeni na fundamentalnim pokazateljima slijedeći rad Arnott et al. (2005.). Osnovna ideja vezana uz primjenu fundamentalnih pokazatelja je shvaćanje prema kojemu je poželjno koristiti fundamentalne pokazatelje poslovanja poduzeća kao što su knjigovodstvena vrijednost vlasničke glavnice, prodaja, dividende i sl., budući da oni otkrivaju više o samome poduzeću od tržišne kapitalizacije. Neki pružatelji takvih indeksa isticali su mogućnost signaliziranja potencijala rasta vrijednosti dionice putem pokazatelja na kojima se

Ovaj nedostatak umanjen je kod indeksa temeljenih na tržišnoj kapitalizaciji koji uvode ograničenja na pondere poput tzv. „free float factora“ i sl., jer se time smanjuje izloženost dionicama koje imaju veliku tržišnu kapitalizaciju. 
indeksi temelje (Amenc et al., 2008., str. 5.). Takvi indeksi, dakle, nemaju izravnu vezu s financijskom teorijom nego jednostavno zamjenjuju tržišnu kapitalizaciju različitom mjerom veličine poduzeća koja se temelji na spomenutim varijablama (Amenc et al., 2013., str. 28.).

Arnott et al. (2005.) u svojoj analizi na tržištu SAD-a u razdoblju od 43 godine promatrali su šest fundamentalnih pokazatelja: knjigovodstvenu vrijednost vlasničke glavnice, prosječni petogodišnji novčani tok, prosječni petogodišnji prihod, prosječnu petogodišnju prodaju, prosječne petogodišnje dividende te ukupnu zaposlenost. Istraživanjem su pokazali kako se primjenom fundamentalnih pokazatelja pri ponderiranju može doprinijeti diversifikaciji i dekoncentraciji indeksa čime se postiže bolji odnos rizika i nagrade nego u slučaju primjene tržišne kapitalizacije. Upravo je njihovo vjerovanje u rezultate analize koju ne smatraju slučajnošću povijesti ili nekom anomalijom upravljanja portfolijem potaknulo analizu indeksa temeljenih na fundamentalnim pokazateljima na hrvatskome tržištu kapitala.

Amenc et al. (2008.) ističu da se u praksi indeksi temeljeni na fundamentalnim pokazateljima mogu razlikovati od indeksa temeljenih na tržišnoj kapitalizaciji na 2 načina (Amenc et al., 2008., str. 5. i 8.):

1. Odabir sastavnica indeksa se može temeljiti na fundamentalnim pokazateljima (dok se dodjeljivanje pondera ponekada može bazirati i na tržišnoj kapitalizaciji) i

2. Ponderi se određuju temeljem fundamentalnih pokazatelja (dok sastavnice indeksa mogu biti iste kao i u slučaju indeksa temeljenog na tržišnoj kapitalizaciji).

U ovome radu primijenjen je samo drugi način određivanja indeksa kako bi predloženi indeksi bili što sličniji CROBEX-u. Od prethodno navedenih fundamentalnih pokazatelja koje su koristili Arnott et al. (2005.) u ovoj analizi koriste se pokazatelji knjigovodstvene vrijednosti vlasničke glavnice, prosječnog prihoda i ukupne zaposlenosti. S ciljem boljeg prilagođavanja specifičnostima hrvatskoga tržišta kapitala ostali pokazatelji iz spomenutoga istraživanja izbačeni su iz analize, a dodatno su u analizu uvedeni: neto dobit, EBIT, EBITDA i omjer cijene i zarada (P/E omjer). Podaci o dividendama, primjerice, imaju važnu ulogu na financijskome tržištu SAD-a, dok nemaju gotovo nikakvu na hrvatskome tržištu. ${ }^{3}$ Zbog daleko manjeg broja poduzeća u analizi, a i zbog njihove daleko niže profitabilnosti, nego što je slučaj u istraživanju Arnott et al. (2005.) umjesto novčanog toka i dodatne mjere prihoda, naglasak je stavljen na 3 mjere profita: neto dobit, EBIT i EBITDA. $\mathrm{P} / \mathrm{E}$ omjer je dodan jer se obično ističe kao važan, odnosno, informativan pokazatelj investitorima, a i kao kontrolna varijabla budući da u sebi kroz cijenu dionice sadrži podatak o tržišnoj kapitalizaciji.

Osim indeksa kreiranih prema navedenim fundamentalnim pokazateljima, dodatno je kreiran jedan kombinirani indeks (u nastavku Kompozitni indeks) u kojemu pet pokazatelja (prihodi, dobit, broj zaposlenih, EBIT i knjigovodstvena vrijednost vlasničke glavnice) imaju iste pondere. Dodjeljivanje istih pondera fundamentalnim pokazateljima predstavlja pojednostavljeni način dekoncentriranja portfolia te naivni način sastavljanja diversificiranog portfolia ${ }^{4}$.

Više o tome vidjeti u Kožul (2012.).

Navedeno se naziva 1/N pravilo. Više o tome vidjeti u Amenc et al. (2013.). 
Ponderiranje zapisano formulom moguće je prikazati na sljedeći način:

$$
w_{i}=\frac{F P_{i}}{\sum_{i=1}^{N} F P_{i}}
$$

pri čemu je $w_{i}$ ponder pojedine sastavnice indeksa, a $F P_{i}$ njezin fundamentalni pokazatelj.

\section{OPIS PODATAKA}

Istraživanje ovoga članka temelji se na CROBEX indeksu, najstarijem i najvećem indeksu na hrvatskome financijskom tržištu koji je uveden 1997. godine. Taj indeks nije temeljen isključivo na tržišnoj kapitalizaciji. Treba naglasiti kako su udjeli pojedinih sastavnica u njemu određeni na temelju ,free float“ tržišne kapitalizacije, pri čemu je težina pojedine dionice dodatno ograničena na 10\%. CROBEX indeks je cjenovni indeks što znači da se dividende ne uključuju u njegov sastav. ${ }^{5}$

U ovome radu kreirani su indeksi temeljem fundamentalnih pokazatelja koji će se usporediti s CROBEX indeksom prema kriterijima prinosa i rizika. Prilikom prikupljanja potrebnih podataka bitan ograničavajući faktor predstavlja relativna netransparentnost tržišta te nepostojanje obveze standardiziranog izvještavanja poduzeća uvrštenih u kotaciju burze što je odredilo uzorak prikupljenih podataka. Razdoblje u kojemu se provodi analiza uspješnosti indeksa temeljenih na fundamentalnim pokazateljima nasuprot CROBEX indeksu počinje s redovitom revizijom indeksa 23. 3. 2009. godine, a završava sa 16. 9. 2016. godine. U promatranome razdoblju ukupno je provedeno petnaest redovnih revizija indeksa. CROBEX je bio sastavljen najmanje od 21 dionice, a najviše od 25 dionica po reviziji s prosjekom od 24 dionice u cjelokupnom promatranom razdoblju.

Pri kreiranju indeksa, sastav pojedinog indeksa temeljenog na fundamentalnim pokazateljima jednak je sastavu indeksa CROBEX za svaku pojedinu reviziju. Prinosi sastavnica CROBEX indeksa izračunati su za svaku pojedinu reviziju temeljem promjene cijene pojedine dionice (cijena na završni dan revizije u odnosu na cijenu na početni dan revizije). Ponderi dionica u indeksu temeljenom na fundamentalnom pokazatelju računali su se na temelju trogodišnjih prosjeka pojedinog fundamentalnog pokazatelja (za prethodne tri godine). Tako izračunati ponderi koristili su se za izračun prinosa indeksa temeljenog na fundamentalnim pokazateljima izvan uzorka za narednih 6 mjeseci. Podaci izvan uzorka uspoređeni su s CROBEX-om. Budući da je analizom obuhvaćeno petnaest redovnih revizija, obavljeno je rebalansiranje petnaest puta.

U situaciji gdje je trogodišnji prosjek pojedinog fundamentalnog pokazatelja negativan, ponder dodijeljen dionici za zadanu reviziju je 0. Dodjeljivanje negativnih pondera bi pretpostavljalo kratku prodaju koja prema trenutnoj regulativi nije dozvoljena, stoga su u situacijama negativnih pokazatelja dionice isključene iz sastava indeksa. 


\section{REZULTATI ISTRAŽIVANJA}

Primjenom opisanih postupaka $u$ drugom i trećem poglavlju, dobivene su performanse indeksa temeljenih na fundamentalnim pokazateljima prikazane u tablici 1.

Tablica 1.: Performanse indeksa temeljenih na fundamentalnim pokazateljima 2009. - 2016.

\begin{tabular}{|l|c|c|c|c|}
\hline Indeks & $\begin{array}{c}\text { Geometrijski } \\
\text { prinos* }\end{array}$ & $\begin{array}{c}\text { Ukupan } \\
\text { prinos }\end{array}$ & Volatilnost & $\begin{array}{c}\text { Odnos rizika } \\
\text { i nagrade }\end{array}$ \\
\hline Prihodi & $\mathbf{2 , 8 6 \%}$ & $\mathbf{5 2 , 5 5 \%}$ & $\mathbf{2 2 , 7 8 \%}$ & $\mathbf{0 , 1 2 5 4}$ \\
\hline Dobit & $0,79 \%$ & $12,52 \%$ & $18,92 \%$ & 0,0417 \\
\hline EBITDA & $1,76 \%$ & $29,91 \%$ & $19,28 \%$ & 0,0913 \\
\hline Broj zaposlenih & $\mathbf{2 , 9 4 \%}$ & $\mathbf{5 4 , 5 0 \%}$ & $\mathbf{1 9 , 4 7 \%}$ & $\mathbf{0 , 1 5 1 1}$ \\
\hline EBIT & $1,73 \%$ & $29,31 \%$ & $19,42 \%$ & 0,0890 \\
\hline P/E & $0,11 \%$ & $1,62 \%$ & $19,53 \%$ & 0,0055 \\
\hline $\begin{array}{l}\text { Knjigovodstvena vrijednost } \\
\text { vlasničke glavnice }\end{array}$ & $\mathbf{2 , 2 6 \%}$ & $\mathbf{3 9 , 7 7 \%}$ & $\mathbf{1 8 , 1 8 \%}$ & $\mathbf{0 , 1 2 4 2}$ \\
\hline Kompozitni indeks & $\mathbf{2 , 2 0 \%}$ & $\mathbf{3 8 , 5 2 \%}$ & $\mathbf{1 9 , 2 8 \%}$ & $\mathbf{0 , 1 1 3 9}$ \\
\hline CROBEX & $2,09 \%$ & $36,32 \%$ & $18,53 \%$ & 0,1126 \\
\hline
\end{tabular}

* Prikazani prosječni prinosi su geometrijske sredine koje su izračunate temeljem polugodišnjih prinosa.

Izvor: izračun autora.

Temeljem prikazanih rezultata u razdoblju od 15 redovnih revizija (vidjeti i Dodatak 1.), uočava se kako su ukupno četiri od osam indeksa temeljenih na fundamentalnim pokazateljima ostvarili bolji prinos, ali i rezultat mjeren odnosom rizika i nagrade u odnosu na CROBEX indeks. Najveći ukupni prinos ostvaruje indeks temeljen na fundamentalnom pokazatelju broj zaposlenih s ukupnim prinosom od 54,50\% što predstavlja pozitivnu razliku od 18,18 postotnih poena (p.p.) u odnosu na CROBEX. Svega 1,95 p.p. lošiji rezultat u odnosu na indeks temeljen na broju zaposlenih daje indeks temeljen na prihodima, što je i dalje značajnih 16,23 p.p. prinosa iznad CROBEX-a odnosno 0,77 p.p. pozitivne razlike po reviziji. Uz prihode i broj zaposlenih, prinos viši od CROBEX-a dali su indeks temeljen na knjigovodstvenoj vrijednosti vlasničke glavnice poduzeća te Kompozitni indeks.

Od navedenih samo je indeks temeljen na knjigovodstvenoj vrijednosti vlasničke glavnice imao manju volatilnost mjerenu standardnom devijacijom, ali razlike $\mathrm{u}$ prinosima $\mathrm{u}$ odnosu na CROBEX su bile dovoljne da sva četiri navedena indeksa imaju viši odnos rizika i nagrade.

Prema uzoru na Arnott et al. (2005.) kao dopuna rezultatima iz tablice 1., u tablici 2. izračunati su koeficijenti asimetrije i zaobljenosti kako bi se dobile dodatne informacije o dobivenoj distribuciji prinosa. Prikazani su i najviši i najniži prinosi po reviziji. 
Tablica 2.: Koeficijenti asimetrije i zaobljenosti odabranih indeksa

\begin{tabular}{|l|c|c|c|c|}
\hline Indeks & $\begin{array}{c}\text { Koeficijent } \\
\text { asimetrije }\end{array}$ & $\begin{array}{c}\text { Koeficijent } \\
\text { zaobljenosti }\end{array}$ & $\begin{array}{c}\text { Najviši prinos } \\
\text { po reviziji }\end{array}$ & $\begin{array}{c}\text { Najniži prinos } \\
\text { po reviziji }\end{array}$ \\
\hline Prihodi & 1,78 & 2,36 & $63,84 \%$ & $-12,71 \%$ \\
\hline Dobit & 2,16 & 6,09 & $62,05 \%$ & $-18,48 \%$ \\
\hline EBITDA & 1,55 & 1,95 & $54,27 \%$ & $-15,11 \%$ \\
\hline Broj zaposlenih & 1,88 & 3,38 & $59,94 \%$ & $-10,94 \%$ \\
\hline EBIT & 1,93 & 4,79 & $62,38 \%$ & $-16,77 \%$ \\
\hline P/E & 1,86 & 4,75 & $60,79 \%$ & $-22,71 \%$ \\
\hline $\begin{array}{l}\text { Knjigovodstvena vrijed- } \\
\text { nost vlasničke glavnice }\end{array}$ & 1,71 & 3,29 & $56,02 \%$ & $-13,50 \%$ \\
\hline Kompozitni indeks & 1,91 & 4,08 & $60,85 \%$ & $-14,23 \%$ \\
\hline CROBEX & 2,18 & 5,57 & $61,30 \%$ & $-12,16 \%$ \\
\hline
\end{tabular}

Izvor: izračun autora.

Zanimljiv je podatak o asimetričnosti prinosa jer je iz tablice moguće uočiti kako su svi koeficijenti asimetrije pozitivni što upućuje na veća odstupanja u smjeru viših prinosa u odnosu na rizik gubitka. Koeficijenti asimetrije su prilično slični i ne odstupaju značajnije od CROBEX-a koji ima najveći koeficijent asimetrije. Kod koeficijenata zaobljenosti uočava se kako su indeksi koji su ostvarili bolje rezultate mjereno prinosom i rizikom (prethodna tablica) bliže normalnoj distribuciji.

U svrhu testiranja robusnosti, zbog financijske krize 2008. godine koja je pogodila i hrvatsko financijsko tržište, analizirano razdoblje moguće je podijeliti u dva razdoblja od kojih se prvo razdoblje od 2009. do 2012. godine odnosi na veću, a drugo od 2013. do 2016. godine na manju volatilnost, što je moguće vidjeti u tablicama u Dodatku 1. i 2. na primjeru kretanja prinosa CROBEX indeksa. Volatilnost CROBEX-a mjerena standardnom devijacijom u prvome razdoblju iznosila je više od $20 \%$, a u drugome je bila ispod $9 \%$. Takva podjela omogućava testiranje robusnosti dobivenih rezultata za cjelokupno promatrano razdoblje.

Tablica 3.: Performanse indeksa temeljenih na fundamentalnim pokazateljima 2009. - 2012.

\begin{tabular}{|l|c|c|c|c|}
\hline Indeks & $\begin{array}{c}\text { Geometrijski } \\
\text { prinos }\end{array}$ & $\begin{array}{c}\text { Ukupan } \\
\text { prinos }\end{array}$ & Volatilnost & $\begin{array}{c}\text { Odnos rizika } \\
\text { i nagrade }\end{array}$ \\
\hline Prihodi & $\mathbf{7 , 8 6 \%}$ & $\mathbf{8 3 , 1 2 \%}$ & $\mathbf{2 9 , 7 7 \%}$ & $\mathbf{0 , 2 6 3 9}$ \\
\hline Dobit & $2,04 \%$ & $17,56 \%$ & $25,54 \%$ & 0,0800 \\
\hline EBITDA & $\mathbf{5 , 4 9 \%}$ & $\mathbf{5 3 , 4 0 \%}$ & $\mathbf{2 4 , 9 6 \%}$ & $\mathbf{0 , 2 2 0 1}$ \\
\hline Broj zaposlenih & $\mathbf{7 , 0 3 \%}$ & $\mathbf{7 2 , 1 9 \%}$ & $\mathbf{2 5 , 6 1 \%}$ & $\mathbf{0 , 2 7 4 4}$ \\
\hline EBIT & $3,26 \%$ & $29,29 \%$ & $26,03 \%$ & 0,1253 \\
\hline P/E & $3,50 \%$ & $31,67 \%$ & $26,17 \%$ & 0,1337 \\
\hline $\begin{array}{l}\text { Knjigovodstvena vrijednost } \\
\text { vlasničke glavnice }\end{array}$ & $\mathbf{6 , 3 6 \%}$ & $\mathbf{6 3 , 7 5 \%}$ & $\mathbf{2 3 , 0 3 \%}$ & $\mathbf{0 , 2 7 6 1}$ \\
\hline Kompozitni indeks & $\mathbf{5 , 3 9 \%}$ & $\mathbf{5 2 , 2 4 \%}$ & $\mathbf{2 5 , 5 1 \%}$ & $\mathbf{0 , 2 1 1 4}$ \\
\hline CROBEX & $4,80 \%$ & $45,51 \%$ & $25,22 \%$ & 0,1903 \\
\hline
\end{tabular}


Iz tablice 3. zanimljivo je uočiti da indeks temeljen na fundamentalnom pokazatelju EBITDA daje bolji prinos od CROBEX-a i to za 0,69 p.p. po reviziji uz manju volatilnost. Osjetno najbolji rezultat daje indeks temeljen na prihodima s velikom razlikom od prosječno 3,06 p.p. po reviziji. Čak pet indeksa temeljenih na fundamentalnim pokazateljima daju bolje prinose od CROBEX-a. Iako su svi imali veću volatilnost u usporedbi s CROBEX indeksom razlike u prinosima osigurale su da svih pet indeksa imaju viši odnos rizika i nagrade.

Tablica 4.: Performanse indeksa temeljenih na fundamentalnim pokazateljima 2013. - 2016.

\begin{tabular}{|l|c|c|c|c|}
\hline Indeks & $\begin{array}{c}\text { Geometrijski } \\
\text { prinos }\end{array}$ & $\begin{array}{c}\text { Ukupan } \\
\text { prinos }\end{array}$ & Volatilnost & $\begin{array}{c}\text { Odnos rizika } \\
\text { i nagrade }\end{array}$ \\
\hline Prihodi & $-2,58 \%$ & $-16,69 \%$ & $12,68 \%$ & $-0,0033$ \\
\hline Dobit & $-0,62 \%$ & $-4,28 \%$ & $9,86 \%$ & $-0,0006$ \\
\hline EBITDA & $-2,35 \%$ & $-15,31 \%$ & $12,91 \%$ & $-0,0030$ \\
\hline Broj zaposlenih & $-1,54 \%$ & $-10,28 \%$ & $10,78 \%$ & $-0,0017$ \\
\hline EBIT & $\mathbf{0 , 0 0 \%}$ & $\mathbf{0 , 0 2 \%}$ & $\mathbf{1 0 , 4 6 \%}$ & $\mathbf{0 , 0 0 0 3}$ \\
\hline P/E & $-3,63 \%$ & $-22,83 \%$ & $8,43 \%$ & $-0,0031$ \\
\hline $\begin{array}{l}\text { Knjigovodstvena vrijednost } \\
\text { vlasničke glavnice }\end{array}$ & $-2,24 \%$ & $-14,64 \%$ & $12,98 \%$ & $-0,0029$ \\
\hline Kompozitni indeks & $-1,34 \%$ & $-9,01 \%$ & $11,12 \%$ & $-0,0015$ \\
\hline CROBEX & $-0,93 \%$ & $-6,32 \%$ & $8,97 \%$ & $-0,0008$ \\
\hline
\end{tabular}

Izvor: izračun autora.

Kao što se može primijetiti na temelju rezultata iz tablice 4., situacija se značajno mijenja od 2013. godine na dalje - niti jedan od indeksa koji su dali bolji rezultat mjeren prinosom i rizikom u razdoblju od 2009. do 2016. godine nije na razini rezultata CROBEX indeksa.

Temeljem rezultata u tablici 4. može se zaključiti kako bolje performanse indeksa temeljenih na fundamentalnim pokazateljima u cjelokupnom razdoblju promatranja proizlaze iz razdoblja veće volatilnosti odnosno razdoblja 2009. - 2012. To upućuje na ovisnost korištenih fundamentalnih pokazatelja o dijelu korištenoga uzorka što znači da rezultati u tablici 1. nisu robusni. U tablici 4. kao bolji od CROBEX-a javlja se indeks temeljen na fundamentalnom pokazatelju EBIT (što nije bio slučaj dosad) koji je zahvaljujući prinosu koji nije negativan, jedini ostvario pozitivan odnos rizika i nagrade.

Kao što je navedeno, u sastavu indeksa CROBEX na početku svake pojedine revizije najviši mogući udio pojedine sastavnice u indeksu je $10 \%$. Indeksi temeljeni na fundamentalnim pokazateljima nisu imali nikakvo ograničenje što se tiče visine udjela (udjeli jedino nisu mogli biti negativni zbog nedopuštenosti kratke prodaje). Kako bi se istražio uzrok loših performansi indeksa temeljenih na fundamentalnim pokazateljima u razdoblju 2013. - 2016. u tablici 5. prikazan je prosječni kumulativni udjel prvih 5 sastavnica svakog pojedinog indeksa za to razdoblje. 
Tablica 5.: Koncentracijski omjeri

\begin{tabular}{|l|c|}
\hline \multicolumn{1}{|c|}{ Indeks } & Koncentracijski omjer \\
\hline Prihodi & $71,69 \%$ \\
\hline Dobit & $86,89 \%$ \\
\hline EBITDA & $82,52 \%$ \\
\hline Broj zaposlenih & $55,61 \%$ \\
\hline EBIT & $88,05 \%$ \\
\hline P/E & $61,31 \%$ \\
\hline Knjigovodstvena vrijednost vlasničke glavnice & $77,41 \%$ \\
\hline CROBEX & $49,48 \%$ \\
\hline
\end{tabular}

Izvor: izračun autora.

Od indeksa temeljenih na fundamentalnim pokazateljima koncentracija je najviša u indeksima temeljenim na dobiti, EBITDA i EBIT, dok najmanju koncentraciju od 55,61\% ima indeks temeljen na broju zaposlenih što, međutim, još uvijek predstavlja veću koncentraciju od CROBEX-a. Navedeni koncentracijski omjeri upućuju na relativno visoku ovisnost indeksa o svega nekoliko dionica.

Visoki koncentracijski omjeri ukazuju na slabu diversifikaciju što je upravo suprotno nastojanjima da se primjenom fundamentalnih pokazatelja ostvare bolji rezultati u odnosu na indekse temeljene na tržišnoj kapitalizaciji. Iz toga razloga prema Amenc et al. (2010.) uvedena je lambda $(\lambda)$ kojom se definira ograničenje, tj. maksimalan udio pojedine sastavnice u indeksu ovisno o broju sastavnica $(\mathrm{N})$. S obzirom na različit broj sastavnica CROBEX-a po reviziji (koji varira od 21 do 25 dionica po indeksu) odlučeno je ispitati fundamentalne pokazatelje uz $\lambda=5$ čime je maksimalan udio pojedine sastavnice (dionice) $\mathrm{u}$ indeksu ograničen rasponom od 20 do $24 \%$ (ovisno o broju sastavnica u pojedinoj reviziji).

Nakon definiranja ograničenja izračunati su novi indeksi temeljeni na fundamentalnim pokazateljima te su rezultati prikazani u nastavku. Ograničenja su najviše pogodila udjele dionica INA-R-A i HT-R-A (gotovo u svim revizijama i gotovo u svakome pokazatelju).

Tablica 6.: Performanse indeksa temeljenih na fundamentalnim pokazateljima 2009. - 2016. uz ograničenje na maksimum $\lambda=5$

\begin{tabular}{|l|c|c|c|c|}
\hline Indeks & $\begin{array}{c}\text { Geometrijski } \\
\text { prinos }\end{array}$ & $\begin{array}{c}\text { Ukupan } \\
\text { prinos }\end{array}$ & Volatilnost & $\begin{array}{c}\text { Odnos rizika } \\
\text { i nagrade }\end{array}$ \\
\hline Prihodi & $2,06 \%$ & $35,80 \%$ & $19,97 \%$ & 0,1032 \\
\hline Dobit & $\mathbf{3 , 2 2 \%}$ & $\mathbf{6 0 , 7 9 \%}$ & $\mathbf{2 2 , 4 9 \%}$ & $\mathbf{0 , 1 4 3 0}$ \\
\hline EBITDA & $\mathbf{3 , 0 2 \%}$ & $\mathbf{5 6 , 1 6 \%}$ & $\mathbf{1 8 , 8 2 \%}$ & $\mathbf{0 , 1 6 0 2}$ \\
\hline Broj zaposlenih & $\mathbf{2 , 6 5 \%}$ & $\mathbf{4 8 , 0 2 \%}$ & $\mathbf{1 9 , 1 8 \%}$ & $\mathbf{0 , 1 3 8 1}$ \\
\hline EBIT & $2,15 \%$ & $37,58 \%$ & $21,36 \%$ & 0,1007 \\
\hline P/E & $-0,80 \%$ & $-11,30 \%$ & $19,40 \%$ & $-0,0015$ \\
\hline $\begin{array}{l}\text { Knjigovodstvena vrijednost } \\
\text { vlasničke glavnice }\end{array}$ & $\mathbf{3 , 5 6 \%}$ & $\mathbf{6 9 , 1 0 \%}$ & $\mathbf{1 8 , 9 9 \%}$ & $\mathbf{0 , 1 8 7 7}$ \\
\hline Kompozitni indeks & $\mathbf{2 , 9 3 \%}$ & $\mathbf{5 4 , 1 3 \%}$ & $\mathbf{1 9 , 8 0 \%}$ & $\mathbf{0 , 1 4 7 8}$ \\
\hline CROBEX & $2,09 \%$ & $36,32 \%$ & $18,53 \%$ & 0,1126 \\
\hline
\end{tabular}

Izvor: izračun autora. 
U odnosu na prethodno prezentirane rezultate, nakon uvođenja ograničenja na maksimum rezultati su vidljivo bolji (vidjeti i Dodatak 2.). Čak je šest indeksa temeljenih na fundamentalnim pokazateljima ostvarilo bolji prinos u odnosu na CROBEX indeks. Osjetno najveći ukupni prinos ostvaruje indeks temeljen na fundamentalnom pokazatelju knjigovodstvene vrijednosti vlasničke glavnice s ukupnim prinosom od čak $69,10 \%$ što predstavlja pozitivnu razliku od 32,78 p.p. u odnosu na CROBEX. Osim indeksa temeljenog na knjigovodstvenoj vrijednosti vlasničke glavnice, prinos viši od CROBEX-a ostvarili su i indeks temeljen na dobiti, EBITDA, broju zaposlenih, EBIT i Kompozitni indeks.

Od navedenih indeksa niti jedan nije imao manju volatilnost mjerenu standardnom devijacijom. Svi indeksi koji su imali veći odnos rizika i nagrade ostvarili su ga zahvaljujući većem prinosu.

Također i u ovom slučaju izračunati su koeficijenti asimetrije i zaobljenosti kako bi se dobile dodatne informacije o dobivenoj distribuciji prinosa uz ograničenje na maksimum. Prikazani su i najviši i najniži prinosi po reviziji.

Tablica 7.: Koeficijenti asimetrije i zaobljenosti odabranih indeksa uz ograničenje na maksimum $\lambda=5$

\begin{tabular}{|l|c|c|c|c|}
\hline Indeks & $\begin{array}{c}\text { Koeficijent } \\
\text { asimetrije }\end{array}$ & $\begin{array}{c}\text { Koeficijent } \\
\text { zaobljenosti }\end{array}$ & $\begin{array}{c}\text { Najviši prinos } \\
\text { po reviziji }\end{array}$ & $\begin{array}{c}\text { Najniži prinos } \\
\text { po reviziji }\end{array}$ \\
\hline Prihodi & 1,95 & 3,82 & $61,87 \%$ & $-12,71 \%$ \\
\hline Dobit & 1,71 & 3,02 & $68,45 \%$ & $-19,33 \%$ \\
\hline EBITDA & 1,63 & 2,71 & $56,81 \%$ & $-15,13 \%$ \\
\hline Broj zaposlenih & 1,89 & 3,59 & $59,50 \%$ & $-10,96 \%$ \\
\hline EBIT & 1,88 & 3,98 & $66,75 \%$ & $-18,80 \%$ \\
\hline P/E & 2,07 & 5,46 & $60,79 \%$ & $-22,70 \%$ \\
\hline $\begin{array}{l}\text { Knjigovodstvena } \\
\text { rrijednost vlasničke } \\
\text { glavnice }\end{array}$ & 1,63 & 2,49 & $57,33 \%$ & $-11,96 \%$ \\
\hline Kompozitni indeks & 1,80 & 3,21 & $60,79 \%$ & $-14,00 \%$ \\
\hline CROBEX & 2,18 & 5,57 & $61,30 \%$ & $-12,16 \%$ \\
\hline
\end{tabular}

Izvor: izračun autora.

Rezultati s ograničenjem na maksimum pokazuju kako se koeficijenti asimetrije nisu značajno promijenili, dok se koeficijent zaobljenosti indeksa temeljenog na fundamentalnom pokazatelju dobit značajno promijenio, tj. približio se normalnoj distribuciji, što nije bio slučaj u prethodnoj analizi.

S obzirom na ranije iskustvo, i kod analize s ograničenjem na maksimum potrebno je testirati robusnost odnosno rezultate za dva dijela uzorka. 
Tablica 8.: Performanse indeksa temeljenih na fundamentalnim pokazateljima 2009. - 2012. uz ograničenje na maksimum $\lambda=5$

\begin{tabular}{|l|c|c|c|c|}
\hline Indeks & $\begin{array}{c}\text { Geometrijski } \\
\text { prinos }\end{array}$ & $\begin{array}{c}\text { Ukupan } \\
\text { prinos }\end{array}$ & Volatilnost & $\begin{array}{c}\text { Odnos rizika } \\
\text { i nagrade }\end{array}$ \\
\hline Prihodi & $\mathbf{6 , 0 2 \%}$ & $\mathbf{5 9 , 6 4 \%}$ & $\mathbf{2 6 , 3 3 \%}$ & $\mathbf{0 , 2 2 8 7}$ \\
\hline Dobit & $5,62 \%$ & $54,92 \%$ & $30,32 \%$ & 0,1855 \\
\hline EBITDA & $\mathbf{6 , 0 3 \%}$ & $\mathbf{5 9 , 7 8 \%}$ & $\mathbf{2 4 , 9 2 \%}$ & $\mathbf{0 , 2 4 2 0}$ \\
\hline Broj zaposlenih & $\mathbf{6 , 6 9 \%}$ & $\mathbf{6 7 , 9 2 \%}$ & $\mathbf{2 5 , 1 2 \%}$ & $\mathbf{0 , 2 6 6 5}$ \\
\hline EBIT & $5,05 \%$ & $48,26 \%$ & $28,79 \%$ & 0,1752 \\
\hline P/E & $1,27 \%$ & $10,64 \%$ & $26,52 \%$ & 0,0480 \\
\hline $\begin{array}{l}\text { Knjigovodstvena vrijednost } \\
\text { vlasničke glavnice }\end{array}$ & $\mathbf{7 , 7 6 \%}$ & $\mathbf{8 1 , 8 0 \%}$ & $\mathbf{2 4 , 4 1 \%}$ & $\mathbf{0 , 3 1 7 8}$ \\
\hline Kompozitni indeks & $\mathbf{6 , 4 5 \%}$ & $\mathbf{6 4 , 8 6 \%}$ & $\mathbf{2 6 , 1 8 \%}$ & $\mathbf{0 , 2 4 6 3}$ \\
\hline CROBEX & $4,80 \%$ & $45,51 \%$ & $25,22 \%$ & 0,1903 \\
\hline
\end{tabular}

Izvor: izračun autora.

Svi indeksi, osim onoga temeljenog na fundamentalnom pokazatelju $\mathrm{P} / \mathrm{E}$, daju bolje prinose od CROBEX-a. U ovome slučaju moguće je istaknuti tek nešto nižu volatilnost indeksa temeljenih na EBITDA, broju zaposlenih i knjigovodstvenoj vrijednosti vlasničke glavnice u odnosu na CROBEX. I u ovome slučaju radi se o boljim rezultatima u odnosu na prethodnu analizu bez ograničenja na maksimum.

Tablica 9.: Performanse indeksa temeljenih na fundamentalnim pokazateljima 2013. - 2016. uz ograničenje na maksimum $\lambda=5$

\begin{tabular}{|l|c|c|c|c|}
\hline Indeks & $\begin{array}{c}\text { Geometrijski } \\
\text { prinos }\end{array}$ & $\begin{array}{c}\text { Ukupan } \\
\text { prinos }\end{array}$ & Volatilnost & $\begin{array}{c}\text { Odnos rizika } \\
\text { i nagrade }\end{array}$ \\
\hline Prihodi & $-2,28 \%$ & $-14,93 \%$ & $11,08 \%$ & $-0,0025$ \\
\hline Dobit & $\mathbf{0 , 5 3 \%}$ & $\mathbf{3 , 7 9 \%}$ & $\mathbf{1 2 , 4 7 \%}$ & $\mathbf{0 , 0 4 2 7}$ \\
\hline EBITDA & $\mathbf{- 0 , 3 3 \%}$ & $\mathbf{- 2 , 2 6 \%}$ & $\mathbf{1 0 , 9 5 \%}$ & $\mathbf{- 0 , 0 0 0 4}$ \\
\hline Broj zaposlenih & $-1,79 \%$ & $-11,85 \%$ & $10,92 \%$ & $-0,0020$ \\
\hline EBIT & $-1,06 \%$ & $-7,20 \%$ & $11,33 \%$ & $-0,0012$ \\
\hline P/E & $-3,11 \%$ & $-19,83 \%$ & $9,68 \%$ & $-0,0030$ \\
\hline $\begin{array}{l}\text { Knjigovodstvena vrijednost } \\
\text { vlasničke glavnice }\end{array}$ & $-1,03 \%$ & $-6,98 \%$ & $11,82 \%$ & $-0,0012$ \\
\hline Kompozitni indeks & $-0,96 \%$ & $-6,51 \%$ & $11,26 \%$ & $-0,0011$ \\
\hline CROBEX & $-0,93 \%$ & $-6,32 \%$ & $8,97 \%$ & $-0,0008$ \\
\hline
\end{tabular}

Izvor: izračun autora.

Zanimljive rezultate pokazuje i tablica 9. Robusne rezultate daje jedino indeks temeljen na pokazatelju EBITDA. Indeks temeljen na pokazatelju dobit ostvario je pozitivan prinos i veći odnos rizika i nagrade, ali u razdoblju veće volatilnosti od 2009. - 2012. ne pokazuje bolji odnos rizika i nagrade pa tako rezultati za indeks temeljen na tom pokazatelju nisu robusni. 
Ako rezultate usporedimo s rezultatima istraživanja Arnott et al. (2005.), u njihovom slučaju indeksi temeljeni na fundamentalnim pokazateljima bili su u prosjeku bolji od S\&P 500 indeksa za 1,97 p.p. godišnje za cjelokupno testirano razdoblje. Rezultati njihove analize potvrđuju superiornost indeksa temeljenih na fundamentalnim pokazateljima is aspekta robusnosti u vidu različitih podjela razdoblja istraživanja (poslovni ciklusi, medvjeđe i bikovsko tržište dionica, okruženje rastućih ili padajućih kamatnih stopa) u odnosu na S\&P 500 indeks koji je temeljen na tržišnoj kapitalizaciji. Međutim, to ovdje nije slučaj. Jedini indeks koji daje bolje performanse od CROBEX-a je onaj temeljen na fundamentalnom pokazatelju EBITDA koji nije korišten u njihovoj analizi. Rezultati koji nisu robusni u ovome slučaju također sugeriraju prisutnost različitih faktora koji djeluju u uvjetima visoke i niske volatilnosti. Također, to što u svim navedenim rezultatima veći odnos rizika i nagrade proizlazi iz većih prinosa sugerira mogućnost postojanja dodatnih faktora rizika kojima se izlažu investitori, a što bi trebalo ispitati u budućem istraživanju te sukladno tome dopuniti ovu analizu.

\section{ZAKLJUČAK}

Značaj moderne teorije portfolija za donošenje investicijskih odluka i danas je neupitan. Međutim, primjena CAPM-a kao najpoznatijeg jedno-faktorskog modela procjenjivanja kapitalne imovine nije bila uspješna. Jedan od ključnih problema predstavlja činjenica da tržišni portfolio naveden u modelu u praksi nije opaziv. Pokušaj pojednostavljene primjene ključnih koncepata modela (npr. beta koeficijenta kao mjere sistematskog rizika) u uvjetima kada se tržišni portfolio zamijeni dioničkim indeksom temeljenim na tržišnoj kapitalizaciji pokazuje se sasvim pogrešnim jer istraživanja pokazuju da takvi indeksi ne nude efikasan odnos rizika i nagrade investitorima.

Kako bi se investitorima ponudili efikasniji indeksi razvijeni su brojni pravci istraživanja uključujući i procjenu portfolia s najvećim Sharpeovim omjerom što predstavlja ujedno i pokušaj rehabilitacije CAPM-a. Budući da istraživanje vezano uz procjenu takvog portfolia na hrvatskome tržištu kapitala nije dalo ohrabrujuće rezultate, u ovome istraživanju mogućnost procjene efikasnijih indeksa ispitana je korištenjem fundamentalnih pokazatelja, iako njihova primjena nema izravne veze s financijskom teorijom. Nasuprot indeksima temeljenim na tržišnoj kapitalizaciji, indeksi temeljeni na fundamentalnim pokazateljima služe se fundamentalnim pokazateljima ili kombinacijom više njih kroz više godina prilikom izračuna pondera pojedinih dionica u indeksu. Takvim pristupom želi se izbjeći previsoka zastupljenost pojedinih dionica $\mathrm{u}$ indeksu čije su cijene u određenom trenutku precijenjene na tržištu te se želi eliminirati mogućnost preslabe zastupljenosti dionica čija je cijena na tržištu podcijenjena. Na taj način trebala bi se osigurati veća diversifikacija kroz smanjenje koncentracije indeksa.

Prilikom testiranja fundamentalnih indeksa na hrvatskome dioničkom tržištu utvrđeno je da određeni indeksi temeljeni na fundamentalnim pokazateljima pokazuju superiorne rezultate u odnosu na CROBEX indeks u promatranome razdoblju (2009. - 2016.). Četiri odabrana indeksa ostvaruju veći prosječni prinos po reviziji od CROBEX-a temeljem kojega ostvaruju i bolje odnose rizika i nagrade. Radi se o fundamentalnim pokazateljima prihod, broj zaposlenih, knjigovodstvena vrijednost vlasničke glavnice te Kompozitnom indeksu. 
Ipak, indeksi temeljeni na navedenim fundamentalnim pokazateljima dali su bolji rezultat od indeksa CROBEX samo u prvom, volatilnijem dijelu ukupnog promatranog razdoblja analize (2009. - 2012.). U kasnijem periodu manje volatilnosti i negativnih prinosa od 2013. godine samo je indeks temeljen na fundamentalnom pokazatelju EBIT ostvario bolje rezultate od CROBEX-a dok su svi ostali indeksi ostvarili lošije rezultate.

Objašnjenje navedenoga može se tražiti u malom broju dionica u sastavu CROBEX-a (od 21 do 25) zbog čega je teško postići bolji diversifikacijski efekt od indeksa CROBEX koji osim toga u samoj formuli za izračun koristi „free float“ faktor te limit od $10 \%$ udjela pojedine dionice u indeksu. Zbog toga je korištenje fundamentalnih pokazatelja ispitano još jednom, uz uvođenje ograničenja na maksimalnu veličinu pondera u vidu parametra lambda $(\lambda)$. Kako bi se postigao veći diversifikacijski efekt definirana je $\lambda=5$ što znači da je maksimalni udjel pojedine dionice u indeksu ograničen na 20\% - 24\% (ovisno o broju sastavnica indeksa u pojedinoj reviziji). Na taj način dobiveni su bolji rezultati. 5 indeksa je ostvarilo bolji odnos rizika i nagrade od CROBEX indeksa u ukupnom promatranom razdoblju (2009. - 2016.), a i razlika u odnosima rizika i nagrade se povećala u korist testiranih indeksa. Međutim, i u ovome slučaju potrebno je istaknuti da bolji odnosi rizika i nagrade promatranih indeksa proizlaze isključivo iz relativno većeg porasta prinosa koje ostvaruju u odnosu na CROBEX, odnosno, da niti jedan indeks ne ostvaruje niži rizik od CROBEX indeksa što bi bila očekivana i priželjkivana posljedica diversifikacijskog efekta. Osim toga, dok u skladu s ranijim rezultatima, u razdoblju veće volatilnosti (2009. - 2012.) ponovno gotovo isti indeksi pokazuju superiorne rezultate u odnosu na CROBEX indeks, situacija se ponovno značajno mijenja kad se promatra razdoblje niske volatilnosti (2013. - 2016.). U tome razdoblju jedino indeks temeljen na EBITDA pokazatelju ponovno demonstrira superiornost nad CROBEX indeksom. Drugi indeks, temeljen na pokazatelju dobit nije imao bolje performanse u razdoblju više volatilnosti.

Navedeni rezultati upućuju na slabu robusnost korištenog pristupa jer je razvidno da dobre performanse analiziranih indeksa u ukupnom promatranom razdoblju ovise o prvome dijelu uzorka u kojemu je vladala veća volatilnost na financijskome tržištu. U drugome dijelu uzorka koji se odnosi na razdoblje niže volatilnosti čini se djeluju drugi čimbenici koje je tek EBITDA pokazatelj uspio obuhvatiti uz primjenu ograničenja na maksimalnu veličinu pondera.

Osim toga, svakako treba primijetiti da je izostao pravi diversifikacijski efekt u smislu ostvarivanja nižeg rizika u odnosu na CROBEX indeks. To je moguće pripisati naivnom principu diversifikacije (koji nema izravnu vezu s financijskom teorijom), a upravo zato potreban je i poseban oprez jer to znači i da predloženi indeksi investitore izlažu rizicima kojih ne moraju biti svjesni. Budući da nije riječ o optimalnom portfoliu iz CAPM-a, niti o pokušaju procjene istog, rizik je sigurno veći od sistematske komponente, a potrebno je provesti dodatno istraživanje kako bi se preciznije otkrili rizici u pozadini predloženih indeksa koji omogućavaju ostvarivanje ekstra-prinosa u odnosu na CROBEX indeks. Ipak, zanimljivo je primijetiti da je korišteni princip diversifikacije polučio bolje rezultate nego pokušaj procjene portfolia s najvećim Sharpeovim omjerom u radu Dolinar et al. (2017.) za slično analizirani vremensko razdoblje. 


\section{LITERATURA:}

1. Amenc, N., Goltz, F., Le Sourd, V. (2006.). Assessing the Quality of Stock Market Indices: Requirements for Asset Allocation and Performance Measurement. Nice: An EDHEC Risk \& Asset Management Research Centre Publication.

2. Amenc, N., Goltz, F., Le Sourd, V. (2008.). A Comparison of Fundamentally Weighted Indices: Overview and Performance Analysis. Nice: EDHEC-Risk and Asset Management Research Centre.

3. Amenc, N., Goltz, F., Martellini, L. (2013.). Smart Beta 2.0. Nice: EDHEC-Risk Institute.

4. Amenc, N., Goltz, F., Martellini, L., Retkowsky, P. (2010.). Efficient Indexation: An Alternative to Cap-Weighted Indices. Nice: An EDHEC-Risk Institute Publication.

5. Arnott, R., Hsu, J., Moore, P. (2005.). Fundamental Indexation. Financial Analysts Journal. 61(2), 83-99.

6. Dolinar, D., Zoričić, D., Kožul, A. (2017.). Towards the Estimation of an Efficient Benchmark Portfolio: The Case of Croatian Emerging Market. Zagreb international review of economics \& business. Special Conference Issue. April, str. 13-24.

7. Goltz, F., Le Sourd, V. (2010.). Does Finance Theory Make the Case for Capitalisation-Weighted Indexing? Nice: An EDHEC-Risk Institute Publication.

8. Grinold, R. C. (1992.) Are Benchmark Portfolios Efficient? The Journal of Portfolio Management. 19(1), 34-40.

9. Haugen, R. A., Baker, N. L. (1991.) The Efficient Market Inefficiency of Capitalization-Weighted Stock Portfolios. The Journal of Portfolio Management. 17(3), 35-40.

10. Kožul, A. (2012.). Faktori oblikovanja politike dividendi, doktorska disertacija, Ekonomski fakultet - Zagreb.

11. Markowitz, H. M. (1952.). Portfolio Selection. The Journal of Finance. 7(1), 77-91.

12. Markowitz, H. M. (1959.). Portfolio Selection: Efficient Diversification of Investments. New York: John Wiley \& Sons, Inc.

13. Markowitz (1984.). The "two beta" trap. The Journal of Portfolio Management. 11(1), 12-20.

14. Orsag, S. (2015.). Investicijska analiza. Avantis, Zagreb. HUFA.

15. Sharpe, W. F. (1964.). Capital Asset Prices: A Theory of Market Equilibrium under Conditions of Risk. The Journal of Finance. 19(3), 425-442.

16. Zoričić, D., Dolinar, D., Kožul, A. (2014.). The Market Index Benchmark and Adequate Compensation for Systematic Risk in an Illiquid and Undeveloped Financial Market. U D. Miloš Sprčić (Ur.) Risk Management: Strategies for Economic Development and Challenges in the Financial System (str. 257-277). New York, SAD: Nova Science Publishers, Inc. 
DODATAK 1.: Prinosi indeksa temeljeni na fundamentalnim pokazateljima za svaku pojedinu reviziju

\begin{tabular}{|c|c|c|c|c|c|c|c|c|c|c|}
\hline & Revizija & Prihodi & Dobit & EBITDA & $\begin{array}{c}\text { Broj } \\
\text { zaposlenih }\end{array}$ & EBIT & $\mathrm{P} / \mathrm{E}$ & $\begin{array}{l}\text { Knjigovodstvena } \\
\text { vrijednost } \\
\text { vlasničke glavnice }\end{array}$ & $\begin{array}{l}\text { Kompozitni } \\
\text { indeks }\end{array}$ & CROBEX \\
\hline \multirow{8}{*}{ 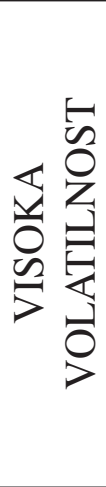 } & 1 & $63,84 \%$ & $62,05 \%$ & $54,27 \%$ & $59,94 \%$ & $62,38 \%$ & $60,79 \%$ & $56,02 \%$ & $60,85 \%$ & $61,30 \%$ \\
\hline & 2 & $1,85 \%$ & $3,11 \%$ & $5,38 \%$ & $1,41 \%$ & $3,53 \%$ & $10,00 \%$ & $4,83 \%$ & $2,94 \%$ & $-3,06 \%$ \\
\hline & 3 & $-10,09 \%$ & $-12,07 \%$ & $-12,04 \%$ & $-9,64 \%$ & $-11,69 \%$ & $-9,99 \%$ & $-10,51 \%$ & $-10,80 \%$ & $-11,88 \%$ \\
\hline & 4 & $51,53 \%$ & $8,03 \%$ & $36,01 \%$ & $36,14 \%$ & $19,42 \%$ & $6,07 \%$ & $24,75 \%$ & $27,97 \%$ & $19,23 \%$ \\
\hline & 5 & $-12,71 \%$ & $-18,48 \%$ & $-15,11 \%$ & $-10,87 \%$ & $-16,77 \%$ & $-22,71 \%$ & $-12,33 \%$ & $-14,23 \%$ & $-12,16 \%$ \\
\hline & 6 & $-5,55 \%$ & $-9,51 \%$ & $-8,74 \%$ & $-3,53 \%$ & $-9,50 \%$ & $-11,19 \%$ & $-4,05 \%$ & $-6,43 \%$ & $-7,14 \%$ \\
\hline & 7 & $-8,73 \%$ & $-9,59 \%$ & $-6,62 \%$ & $-8,42 \%$ & $-11,28 \%$ & $-6,58 \%$ & $-5,74 \%$ & $-8,75 \%$ & $-7,70 \%$ \\
\hline & 8 & $7,05 \%$ & $11,05 \%$ & $9,02 \%$ & $9,60 \%$ & $9,14 \%$ & $21,61 \%$ & $13,10 \%$ & $9,99 \%$ & $17,64 \%$ \\
\hline \multirow{7}{*}{ 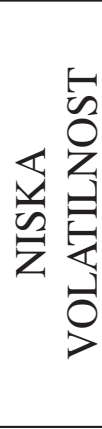 } & 9 & $-8,94 \%$ & $-14,53 \%$ & $-7,73 \%$ & $-10,94 \%$ & $-14,68 \%$ & $-18,06 \%$ & $-7,34 \%$ & $-11,29 \%$ & $-8,91 \%$ \\
\hline & 10 & $-9,69 \%$ & $-5,91 \%$ & $-9,13 \%$ & $-7,19 \%$ & $-5,53 \%$ & $-6,48 \%$ & $-7,83 \%$ & $-7,23 \%$ & $-2,62 \%$ \\
\hline & 11 & $12,02 \%$ & $12,96 \%$ & $12,14 \%$ & $10,28 \%$ & $17,14 \%$ & $2,01 \%$ & $12,98 \%$ & $13,08 \%$ & $7,52 \%$ \\
\hline & 12 & $-10,57 \%$ & $-6,94 \%$ & $-9,44 \%$ & $-9,16 \%$ & $-5,36 \%$ & $-11,79 \%$ & $-13,50 \%$ & $-9,11 \%$ & $-9,56 \%$ \\
\hline & 13 & $-5,29 \%$ & $-4,68 \%$ & $-5,69 \%$ & $-1,85 \%$ & $-6,22 \%$ & $-0,82 \%$ & $-2,55 \%$ & $-4,12 \%$ & $-0,73 \%$ \\
\hline & 14 & $-11,18 \%$ & $2,97 \%$ & $-11,29 \%$ & $-5,96 \%$ & $4,91 \%$ & $-0,26 \%$ & $-10,78 \%$ & $-4,01 \%$ & $-4,93 \%$ \\
\hline & 15 & $20,20 \%$ & $15,35 \%$ & $18,90 \%$ & $17,39 \%$ & $13,78 \%$ & $13,14 \%$ & $17,62 \%$ & $16,87 \%$ & $15,06 \%$ \\
\hline & $\begin{array}{c}\text { Geometrijska } \\
\text { sredina } \\
\text { (prinos) } \\
\end{array}$ & $2,86 \%$ & $0,79 \%$ & $1,76 \%$ & $2,94 \%$ & $1,73 \%$ & $0,11 \%$ & $2,26 \%$ & $2,20 \%$ & $2,09 \%$ \\
\hline & $\begin{array}{c}\text { Standardna } \\
\text { devijacija } \\
\text { (Volatilnost) }\end{array}$ & $22,78 \%$ & $18,92 \%$ & $19,28 \%$ & $19,47 \%$ & $19,42 \%$ & $19,53 \%$ & $18,18 \%$ & $19,28 \%$ & $18,53 \%$ \\
\hline
\end{tabular}

Izvor: izračun autora. 
DODATAK 2.: Prinosi indeksa temeljeni na fundamentalnim pokazateljima za svaku pojedinu reviziju uz ograničenje na maksimum $\lambda=5$

\begin{tabular}{|c|c|c|c|c|c|c|c|c|c|c|}
\hline & Revizija & Prihodi & Dobit & EBITDA & $\begin{array}{c}\text { Broj } \\
\text { zaposlenih }\end{array}$ & EBIT & $\mathrm{P} / \mathrm{E}$ & $\begin{array}{c}\text { Knjigovodstvena } \\
\text { vrijednost } \\
\text { vlasničke glavnice }\end{array}$ & $\begin{array}{l}\text { Kompozitni } \\
\text { indeks }\end{array}$ & CROBEX \\
\hline \multirow{8}{*}{ 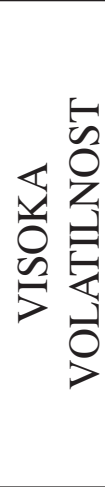 } & 1 & $61,87 \%$ & $68,45 \%$ & $56,81 \%$ & $59,50 \%$ & $66,75 \%$ & $60,79 \%$ & $57,33 \%$ & $60,79 \%$ & $61,30 \%$ \\
\hline & 2 & $0,91 \%$ & $-0,20 \%$ & $2,38 \%$ & $1,19 \%$ & $1,20 \%$ & $-7,68 \%$ & $3,48 \%$ & $1,55 \%$ & $-3,06 \%$ \\
\hline & 3 & $-10,43 \%$ & $-11,22 \%$ & $-11,04 \%$ & $-9,68 \%$ & $-11,37 \%$ & $-9,99 \%$ & $-10,34 \%$ & $-10,54 \%$ & $-11,88 \%$ \\
\hline & 4 & $33,73 \%$ & $39,90 \%$ & $32,46 \%$ & $33,49 \%$ & $33,73 \%$ & $6,07 \%$ & $33,73 \%$ & $34,66 \%$ & $19,23 \%$ \\
\hline & 5 & $-12,71 \%$ & $-19,33 \%$ & $-15,13 \%$ & $-10,87 \%$ & $-18,80 \%$ & $-22,70 \%$ & $-11,96 \%$ & $-14,00 \%$ & $-12,16 \%$ \\
\hline & 6 & $-5,81 \%$ & $-8,82 \%$ & $-7,10 \%$ & $-3,53 \%$ & $-9,02 \%$ & $-11,10 \%$ & $-2,92 \%$ & $-5,64 \%$ & $-7,14 \%$ \\
\hline & 7 & $-8,73 \%$ & $-9,18 \%$ & $-5,49 \%$ & $-8,42 \%$ & $-8,11 \%$ & $-6,58 \%$ & $-5,38 \%$ & $-7,44 \%$ & $-7,70 \%$ \\
\hline & 8 & $8,73 \%$ & $11,07 \%$ & $13,33 \%$ & $9,60 \%$ & $9,18 \%$ & $21,61 \%$ & $15,15 \%$ & $11,58 \%$ & $17,64 \%$ \\
\hline \multirow{9}{*}{ 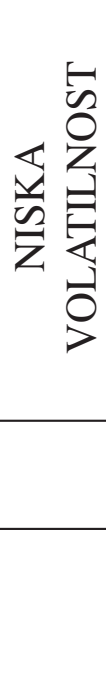 } & 9 & $-11,25 \%$ & $-14,25 \%$ & $-7,87 \%$ & $-10,96 \%$ & $-13,81 \%$ & $-16,57 \%$ & $-7,94 \%$ & $-10,46 \%$ & $-8,91 \%$ \\
\hline & 10 & $-7,32 \%$ & $-5,91 \%$ & $-6,08 \%$ & $-7,19 \%$ & $-5,71 \%$ & $-6,48 \%$ & $-6,70 \%$ & $-6,64 \%$ & $-2,62 \%$ \\
\hline & 11 & $8,86 \%$ & $15,09 \%$ & $12,16 \%$ & $10,04 \%$ & $15,59 \%$ & $2,82 \%$ & $12,26 \%$ & $11,68 \%$ & $7,52 \%$ \\
\hline & 12 & $-10,72 \%$ & $-6,75 \%$ & $-11,95 \%$ & $-10,72 \%$ & $-10,72 \%$ & $-10,72 \%$ & $-10,72 \%$ & $-10,18 \%$ & $-9,56 \%$ \\
\hline & 13 & $-4,08 \%$ & $-3,48 \%$ & $-3,38 \%$ & $-1,80 \%$ & $-4,50 \%$ & $-0,82 \%$ & $-1,40 \%$ & $-2,83 \%$ & $-0,73 \%$ \\
\hline & 14 & $-6,14 \%$ & $3,32 \%$ & $0,45 \%$ & $-5,82 \%$ & $2,72 \%$ & $-0,26 \%$ & $-8,52 \%$ & $-3,34 \%$ & $-4,93 \%$ \\
\hline & 15 & $18,20 \%$ & $20,20 \%$ & $17,85 \%$ & $17,39 \%$ & $12,80 \%$ & $13,14 \%$ & $19,81 \%$ & $18,69 \%$ & $15,06 \%$ \\
\hline & $\begin{array}{c}\text { Geometrijska } \\
\text { sredina (prinos) }\end{array}$ & $2,06 \%$ & $3,22 \%$ & $3,02 \%$ & $2,65 \%$ & $2,15 \%$ & $-0,80 \%$ & $3,56 \%$ & $2,93 \%$ & $2,09 \%$ \\
\hline & $\begin{array}{l}\text { Standardna } \\
\text { devijacija } \\
\text { (Volatilnost) }\end{array}$ & $19,97 \%$ & $22,49 \%$ & $18,82 \%$ & $19,18 \%$ & $21,36 \%$ & $19,40 \%$ & $18,99 \%$ & $19,80 \%$ & $18,53 \%$ \\
\hline
\end{tabular}

Izvor: izračun autora. 